Tarih Kültür ve Sanat Araştırmaları Dergisi

Revue des Recherches en Histoire Culture et Art مجلة البحوث التاريخية والثقافية والفنية
Vol. 6, No. 1, February 2017

Copyright (C) Karabuk University http://kutaksam.karabuk.edu.tr

\title{
DOI: 10.7596/taksad.v6i1.761
}

Citation: Rahmani, A., \& Pashazanoos, A. (2017). Study the Stylistics of "Ashbah" sermon of "Nahjol Balaqeh". Journal of History Culture and Art Research, 6(1), 566-585. doi:http://dx.doi.org/10.7596/taksad.v6i1.761

\section{Study the Stylistics of "Ashbah" sermon of "Nahjol Balaqeh"}

\author{
Atefeh Rahmani*1, Ahmad Pashazanoos $^{2}$
}

\begin{abstract}
Stylistics study the language features of literary text and try to use the tools of linguistics in order to reveal the effects of the beauty of a literary work and public property of it. Such studies are looking for common points in all literary works of scholar which can be fulfilled with studying a part of his works and sometimes explore the effects of stylistics on a certain theme by means of stylistics tools and because stylistics researches often have arbitrary and relative laws that study in this area depends on the nature of critic and taste. In this study it was tried to investigate the coordination of choice of words with sound and sentence structure, vocabulary eloquence and coordination of the structure of sentences with content, to indicate that in this sermon all three levels: phonology, syntax and lexicon have been used to represent the proportion of words and meaning.
\end{abstract}

Keywords: Imam Ali, Nahjol Balaqeh, Ashbah Sermon, Aesthetics, Stylistics.

\footnotetext{
${ }^{1}$ Corresponding Author, M.A. Student, Faculty of Linguistics, Imam Khomeini International University, Qazvin, Iran.

${ }^{2}$ Assistant Prof. Faculty of Linguistics, Imam Khomeini International University, Qazvin, Iran.
} 


\section{Introduction}

Stylistics investigation in the study of literary works, creates a relationship between language subject and literary style, therefore "stylistics is a description of the literary text that has been established on the basis of linguistics" (Masdi, 1947).

This theory indicates that the literary text in the first place is a linguistic text and without analyzing linguistic ties that implies not being quantifiable for criticism and assessment, therefore the literary text is primarily a linguistic innovation and stylistics investigations is research skills in the world of language, this practice is devoted to innovation and it is being used to know the differentiation of their works, to discover the specific literary language of each scholar, which is used consciously or unconsciously (Rizqa, 2002).

Abdo Rajehi, about the difference between linguistics and stylistics, says "linguistics is concerned on the study of "what" is said in the language, but stylistics is concerned in the study of "how" to express what is in the language" (Rajehi, 1981). So this "how" points to the difference and distinction of literary language with uniformity and similarity of indicative and general language. The stylistics scholars believe that the language of poetry has these features that breaks down the principles and general rules of language and makes its own rules which is often not consistent with the rules of the standard language, therefore it is required to look at poetry as a deviation from the standard language and stylistics knowledge task is to examine the features of this deviation (Ayyad, 1981).

Pioneers of the stylistics are to indicate that the nature of a literary work depends on its linguistic structure and it is not required to split the literary work in terms of form and significant and says if the meaning states the feelings, thoughts and emotions, all this can be found in the linguistic aspects (Shamisa, 2002). The concept of structure is very broad for them so that it contains the structure of the literary elements such as: vocabulary, imageries, metaphors, music and etc. Therefore the desired meaning of the scholar is obtained with combination of all these elements. Stylistics believe that the distinguishing feature of the literary text is deviation and its exit from normal language by means of phonetic balance or the used defamiliarization in it, therefore they believe that structural and aesthetic values in a literary work transcends the idea, imagination and emotion, in the sense that literary value is in its artistic structure (Wahba, 1974). Therefore they look at the literary text as a linguistic structure or a distinctive stylistic system. According to these descriptions the stylistic analysis due to make literary works from any external factors such as political, social, psychological, etc., looks at the work as a linguistic structure (Agilton, 1995). 
It is worth noting that Nahjol Balaqeh, is a prolific book that includes the words of Imam Ali (peace upon him) and the most striking features of this valuable book is using speech, writing, beautiful and charming literature, and with the rhetoric criteria, is an example of beauty that Amir, the leader of speech and rhetoric, is the source of it. Deep meanings of words and verbal and interpretive attractions, consistency in meaning and structure are of verbal arts that make the audience captivated. Imam Ali in Nahjol Balaqeh, to create an artistic and beautiful painting has used the before mentioned verbal art. And also by using imaging elements such as analogies, he is to understand the issues and rational arguments.

Imam Ali (peace upon him) in addition to utilization of the benefit of suitable vocabularies and eloquent words has created rhythm and a particular music which penetrates the audience and provokes the feelings. It is obvious that Amir has used the musical terms with no-frills and artificiality because using harmonious words in addition to adding to the verbal beauty, it helps to understanding and keeping the word and also it reduces the indisposition of audience and the use of these virtues are in the service of meaning therefore it leaves a great impact on the psyche of the audience. George Jardaq in this regard says that:

Ali ibn Abi Talib has used the rich taste of art and verbal beauty of expression, as in those days privileged him from others. The form of speech is interwoven with the concept; such as warmth of the fire and light of the sun and the air with the atmosphere, and after encountering to these expressions you are, as if against a raging flood and stormy sea and blowing gust and as it is speaking about the clarity of being and the beauty of the creation of the universe, it is as if writing on your entity with pens from the sky stars. Its speech is as if flares in a dark winter nights and laugh of the sky (Jardaq, 1987).

Therefore it can be said the beauty of Nahjol Balaqeh has privileges in terms of verbal and literary style and is a rich resource for the Arabic language also as there is a proportions in terms of style and content as well as compatibility between all literary elements, using all of them has added to the beauty Nahjol Balaqeh.

\section{The research questions}

This study seeks an answer for the following questions:

How to prove that there is relevance and appropriateness between the phonetic level and the concept of sermon? 
How to prove the proportion of the choice of words with meaning, the sound of the word and structure?

How to prove that the level of syntax and sentence structure is consistent with the meaning and content of the sermon?

\section{Literature review}

The prolific book of Nahjol Balaqeh from several perspectives has been explored and considered that a large part of this analysis and studies aimed at understanding the ethical implications, monotheistic and religious of Nahjol Balaqeh, which in this section we will refer to some of them. In the literature of study it should be said that this prolific book in various accounts such as "Description of Ibn Maitham Bahrani and the Ibn Ali Ibn Abi alHadid" has pointed incidentally and dispersedly to some of the aspects of stylistics and books such as "Wonders of Nahjol Balaqeh" by George Jordaq, "An Inspection in the Nahjol Balaqeh Beauty" by Morteza Ghaemi as well as dissertations such as "The Similes and Metaphors in Nahjol Balaqeh" by Siavash Haqjoo, "The Music of Sermons of Nahjol Balaqeh" by Mustafa Taati Ghafoor have pointed to stylistics aspects of this valuable book which are related to this issue.

It should be noted that the division of analyzing the authors has from these works is in the phonetic analysis it is not enough just to bring the beauty of words but the musical aspect which are associated with meaning and feeling should be proved and evaluated to see whether the use of these literary terms is dried and artificial or subtle. Or we have analyzed the connection of choice of words with lexical and phonetic aspects of word, as well as the appropriateness of the sentence structure with meaning and coherence or lack of structural integrity.

\section{Reviewing the methods of stylistics of Ashbah sermon}

\section{Phonetic level}

The phonetic level can be said as the musical level of the text. Arab literature scholars consider music as one of the elements in analyzing the poetry at structuralist critique and it separates the poems musical elements from prose (Meftah, 1981). But that is correct to be acknowledged; prosodic weight of poetry to be distinguishes from prose. As it is said in the 
definition of poetry, it is a word with rhyme and rhythm that is has a special meaning implication (Qudaamah Ben, 1963) because the music is not just belongs to poetry.

\subsection{The internal music}

It is obvious that the scope of this kind of music is much wider than the weight and order. The internal music can be found in various literary terms such as puns, rhymes, derivation, alliteration and etc. This type of music, with repeated signs of phonetic-based language companion, beauty and fitness creates a deviation, and brings pleasure for listener audience. The application of this style of speech, at language context and modes of eloquence is important.

At the following we are examining this kind of music in Ashbah sermon.

\section{Versification}

Versification is one of the nice and mellow tricks that as the common letters in versification are more melodious it would add to beauty of rhyme. The following are examples of types of versification in this sermon:

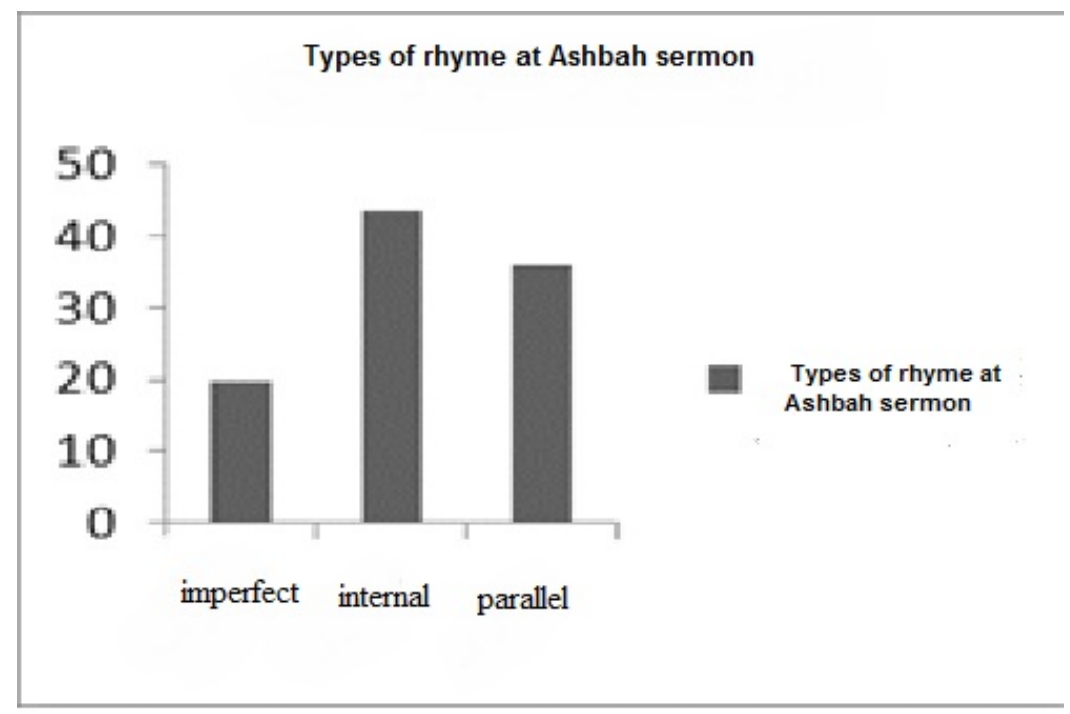

It should be noted that in this sermon, the aesthetic versification context has been achieved in terms of rhythmic rhyme on the direction of symmetry and there's also rhymed words that have caused in alienation and strangeness of speech. Therefore, they have added special and prominent characteristics in the words of a sermon specially to the rhymed words which are 
often key words and meaning of the sermon revolves around these words, given that this implies the proportion of the phonetic level, as one of the means of style.

\section{Inlaying with gems (leonine verse)}

In the phrase:

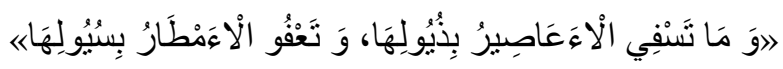

The words بذيولها and الأعاصير are equivalents in the next phrase سيولها الأمطار and سير respectively have parallel rhyme.

\section{Equipoise}

Utilization of this rhetorical figure, in addition to highlighting the beauty of speech also emphasizes the meaning of the word because in this sermon, a second phrase which is equal to the first and somehow repeats the concept of first phrase. In the phrase:

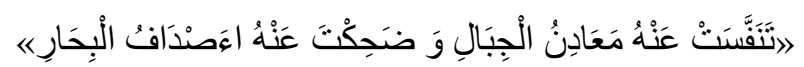

Word of معادن and الجبال respectively is balance with their equivalents in the next sentence . Similarly in the phrase:

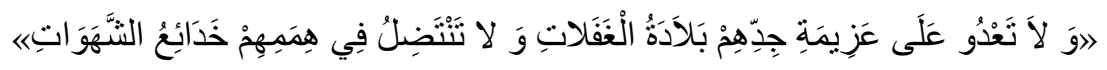

The words of بلادة and الغفلات with their equivalent in the next sentence, خدائع and الثهوات , rhymed balanced.

\section{Couplet}

Because of the multitude of this figure of speech in this sermon we refer to an example:

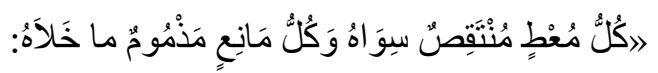

Between مذموم and منص there is rhymed balance and between سو اه too, and and the sum of these two rhymes, there is couplet. 


\section{Alliteration}

In this sermon the sounds of letters and words in addition to adding to the musical aspect have a natural relationship with concepts of sermon too. The following examples refer to it.

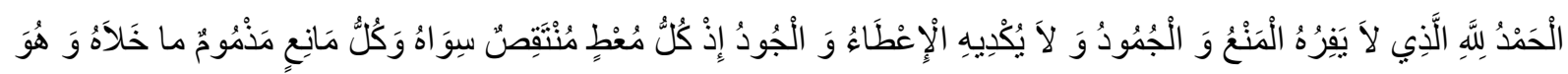

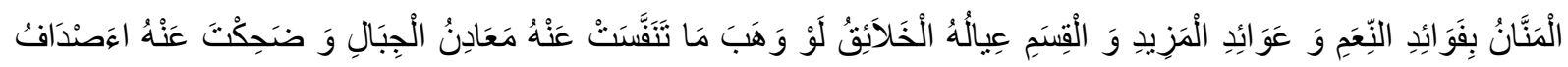

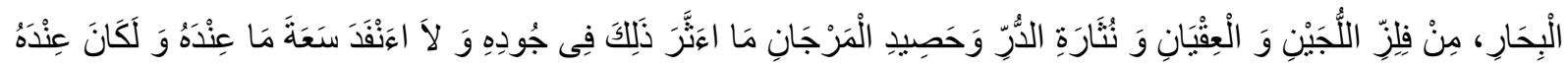

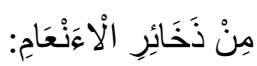

Word " $"$ " means an indication of the forgiveness of God and therefore repeated the word " $\varepsilon$ " in the above passage revolves around the benevolence and generosity of God is appropriate.

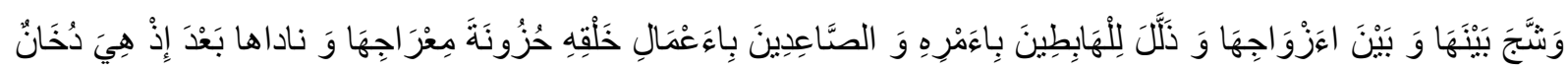

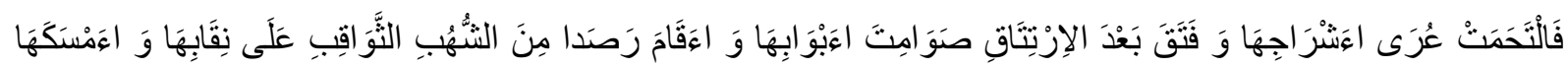

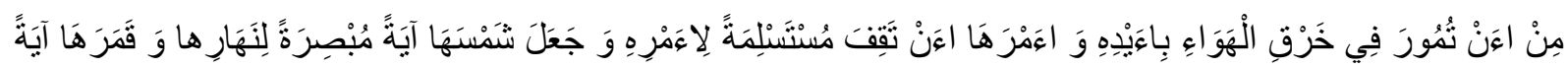

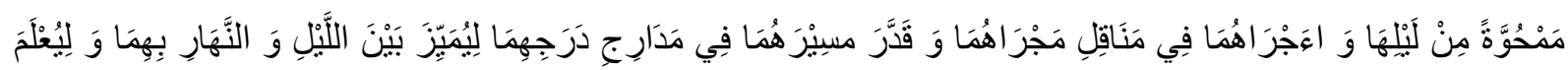

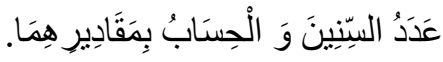

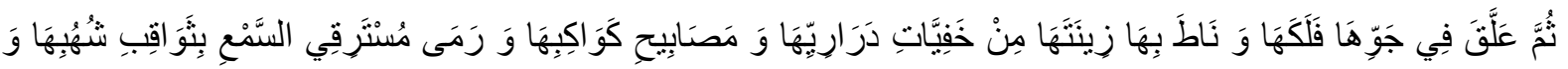

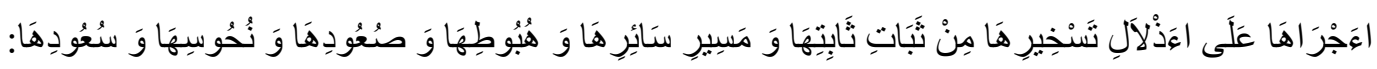

Repetition of the word " $"$ in the above statements suggest calming environment that is consistent with the concept of God because of the creation of the heavens and the elements they brought to mankind.

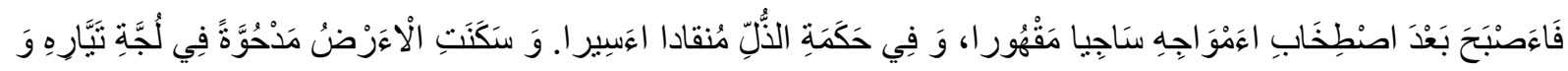

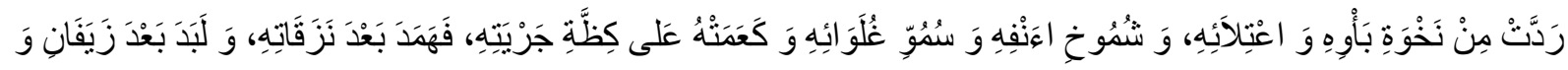

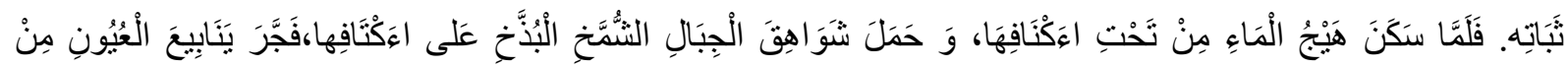

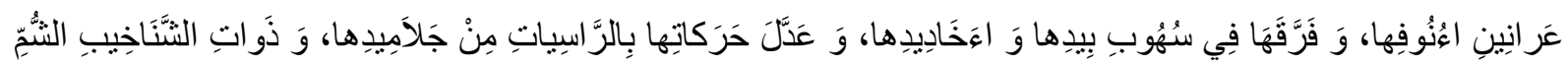
منْ صَنَاخِيِدِا:

Repetition of letters $\dot{\tau}$ and $\tau$ implies the wrath that the use of this word with the meaning of these phrase that is appropriate to anger and roaring waves of the sea.

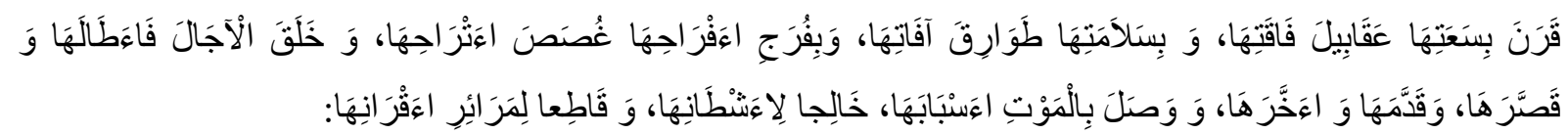

Despite the frequency and vibrating of letter • in a voice it implies the psychological anxiety (Abbas, 1998). Repetition of letter • shows inflamed and disquieting atmosphere that is tested against human states. 


\section{Paregmenon}

In this sermon with the cognate words it is added to the verbal beauty, in the following examples we are referring to.

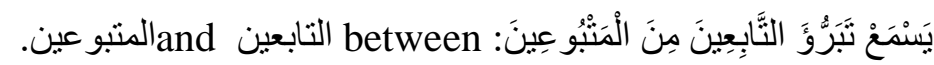

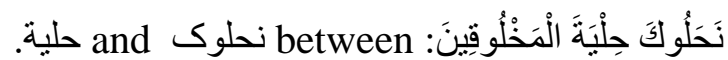

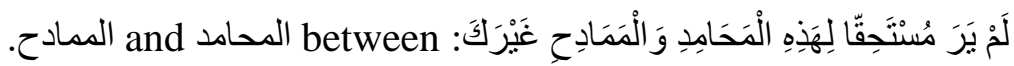

\section{Linear pun}

In the example:

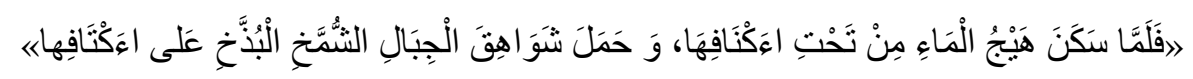

Linear pun is between "اكتافها" and " اكنافها " as we already know all the puns are not beautiful, but the pun between these two words is great, because in addition to being resonate, it is not arid but used in the service of the meaning of the phrases.

\subsection{Spiritual music}

Spiritual music is the set of symmetries, comparisons and contrasts, which is located in the area of semantic and conceptual issues and all the underlying relationships of the components of a literary text; creates the spiritual music of that work and many spiritual imageries like ambiguity, taxis, contrasts, allusions, synesthesia and etc. are in this area of music (Mohseni, 2004). The following are some examples of spiritual music at the Ashbah sermon:

\section{Contradiction}

In this sermon, there is a contradiction between words as mentioned below. However as the used contractions in this sermon were not used for delivering a message and do not have an artificial state, but because of evoking meaning in the mind of the reader and arousing emotions, they have been delivered in different states. Therefore, using these figures has added to the beauty of the sermon.

Affirmative contrast:

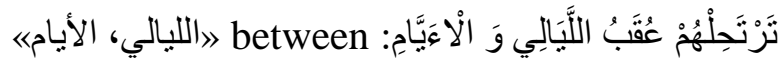

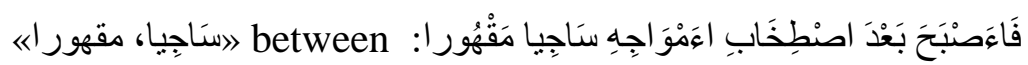




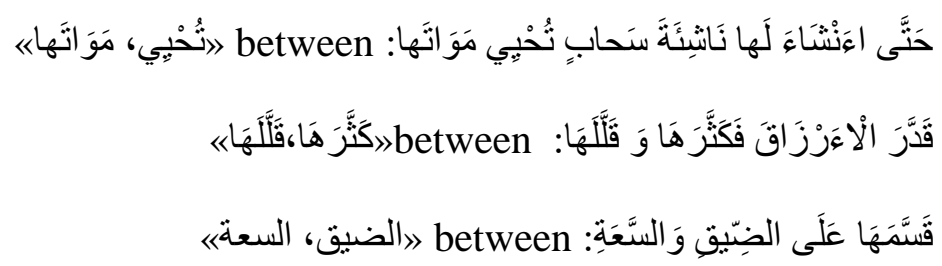

Negative contrast:

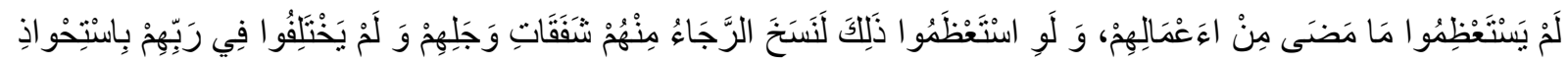

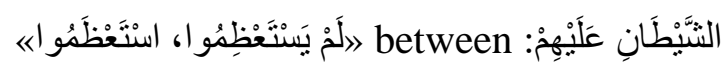

\section{Parallelism}

It is according to new linguistic among the coherence in terms of the wording. In parts of the sermon there are words that have together coherence of meanings in this sermon. Of course, in addition to the sense of proportion of meaning, beauty is also being referred. Look at the following examples.

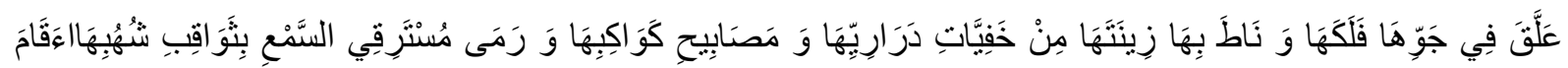

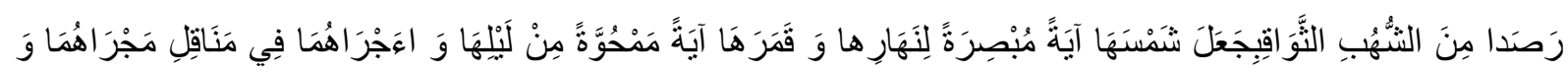

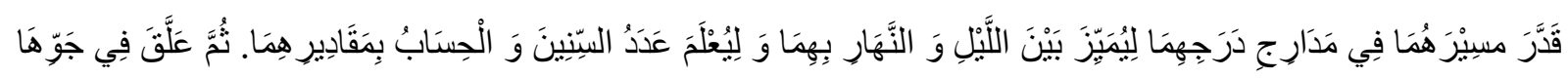

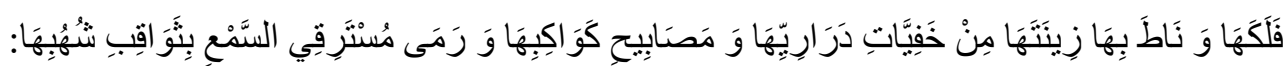
Sun, moon, meteors and stars are all elements of sky. This paragraph is in praise of God in the creation of the heavens and the earth. And that these elements are as evidence of the existence of God and this fact suggests that the parallelism that exists between the words has been delivered to beauty because it is not used as a statement.

\section{Cacophony}

In the phrase:

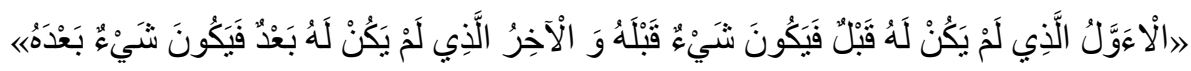

The word الأول with its equivalent بعر and قبله are contrast. 


\section{Lexical level}

First, it must be admitted that the importance of choosing words to convey and deliver the message to the audience is so that the selection method of putting words and terms together, has no effect on the semantic structure; but the effect is applied directly in the structure of message and leads orientation toward the message itself. The sound words, the structure of words and mental concepts of scholar influence the choice of words (Perrin, 1994).

In this sermon, the following factors have influenced the choice of words, such as:

1 - Phonetic aspect, it is important in the choice of words, for example a pun which addressed at the phonetic level has an impact in the choice of words.

2 - Another element in the choice of words in this sermon is the structure of words. Namely, the choice of words in this sermon are as if when words are combined in such a way that the description meaning induce God.

3 - Mental concepts of Imam Ali (peace on him), who praise God and satirizes those who likened God to idols is effective in the choice of words because it has caused to present such concepts with the integration of words.

\subsection{Resolution and strangeness and complexity}

In this sermon, Imam Ali (peace on him) in his expression has utilized a smooth and graceful language, and has chosen his words carefully, he has selected terms and words that can offer their meaning to audience efficiently.

\subsection{Defamiliarization}

It is said "literary work is a substantial through which such words come together that are unrelated from each other in normal use" (Hemase Abdul Latif, 1990: Epic) Therefore Imam has moved beyond the famous rules of language and has created new combinations in order to express his imaginations, emotions and concerns which are monotheistic. That is why in the rhetorical tradition it is called metonymy, because it puts the feet from present reality beyond the domain of language. 


\section{Simile}

One of the most used aesthetic issues is simile that is used in order to ease the understanding of the meaning of sentences.

Eloquent simile:

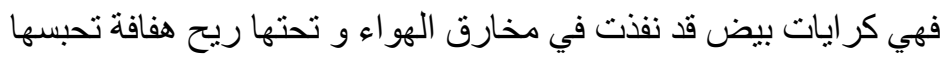

Here is Angel's simile as the imperceptible elements to the white flags and soft winds as tangible elements.

Other similes:

$$
\text { ترغو زبداً كالفحول هياجها: }
$$

The simile of waves of the sea to drunk male camel's simile, shouting and foaming on the lips of moving every way.

\section{Metaphor}

Metaphor is as one of the aesthetics effects, play an essential role in the understanding the concept of this sermon.

Implied metaphor:

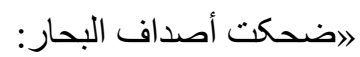

The simile of shells open lips to men who laugh.

$$
\text { ״ناط بها زينتها من خفيات در اريها و مصابيح كو اكبها: }
$$

The simile of luminous and radiant stars in the firmament to beautiful women who adorn themselves.

$$
\text { | اوصلت حقائق الإيمان بينهم و بين معرفته: }
$$

The simile of the facts of the faith to tight strings that have created the necessary link. And...

Stipulated metaphor:

$$
\text { | (لم تجاوز رغباتهم ما عنده إلى ما عند غيره: }
$$

Human interests to his beloved are like the interest of angels to God. 


\section{The use of metonymy}

Metonymy is one of the pillars of aesthetic that below are examples of legitimate metonymies in the Ashbah sermon:

$$
\text { 》اءَمْنَكَهَا مِنْ اعَنْ تُمُورَ فِي خَرْقِ الْهَوَاءِ بِاعَيْدِهِ بِاعَيْدِهِ: }
$$

Metonymy, it is mentioned cause, it implies the convict, it means power.

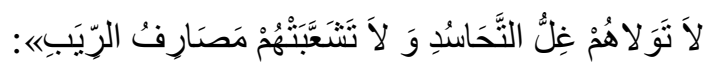

ه : نو لاهم : metonymy, it is mentioned entire, it implies the component.

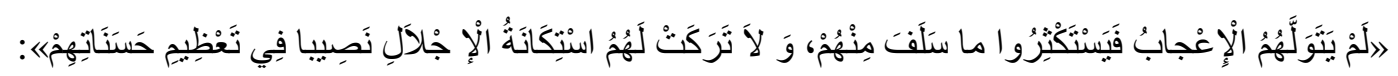

هي ينولهم : metonymy, it is mentioned entire but it implies the component, it means the heart.

\section{Use of irony}

Irony is as one of the elements of imagery and aesthetics issues that is mentioned below examples of emblematic images in this sermon.

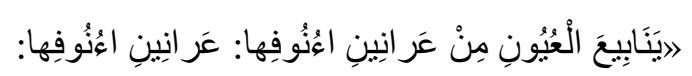

The irony of the mountains.

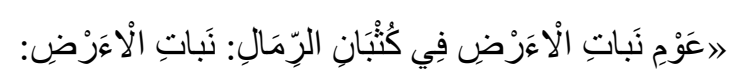

The irony of plants.

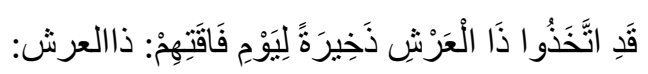

The irony of God.

\subsection{Appropriateness of words and meanings}

From Shams Qais Razi's view, the choice of the appropriate term to imply each meaning are provisions of both in terms of the poet and the most important provisions of the interlocutors. And for each meaning, there are words that scholar chooses words, which due to the structure of the sentence is acceptable. Scholar and orator, in addition to the need to adopt the intended meaning of words, must also choose words that are suitable to the audience's understanding (Excellences element, 1979). Problem with this sermon that can be understood is selection of words according to the context. 


\section{Use of synonyms}

For example, in phrases:

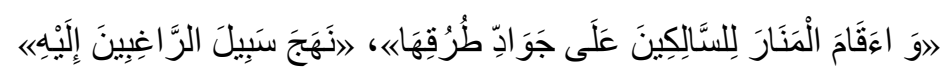

The words "mean the way, but when placed in context they mean something different than their common sense "سبيل " means any kind of way; the usual way, or guided way and the way that leads to astray but in the mentioned passage means the guided way and is used in its original meaning it is applied to refer to the path that is traveled by foot.

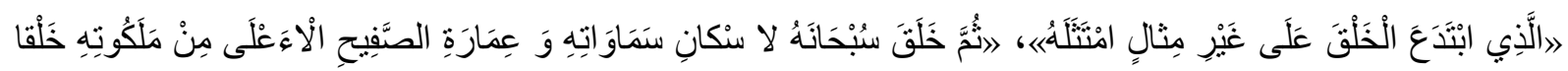

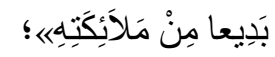
are both mean the creation, but if they come in praise of God like this sermon "خلق" means creating without tools, material and time and space and " ابتدع creating without a template to create creatures.

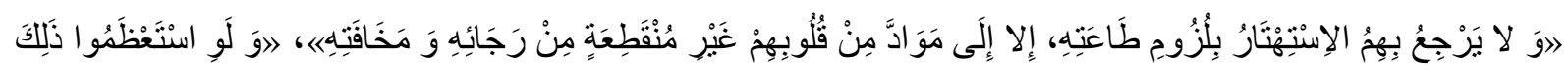

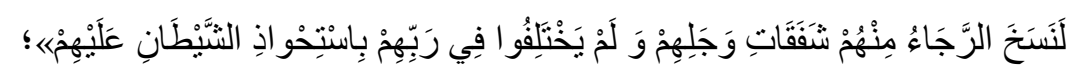

The words, وجلهم and all three mean fear but according to the context, each sentence have been used to demonstrate the appropriateness the word and its meaning. This means that in the preceding statement, "مخافة " means a fear that is made out of the result of the people deeds therefore, use of the word is appropriate to angels' fear from a day that people turn to other than God is so, they do not permit to God's. شققة in the sentence above means a kind of interest and attention that is associated with fear (Raghib Isfahani, 1991). Therefore, in the above passage sympathetic person "angels", while angels have fear of God also are interested in him that the use of the word "شفقة " is appropriate to the concept and also " من " has transitive meaning of fear but if it comes by " من " " في " it would implies more interest. " in the phrase also is given that the word means understand the fear therefore, with great tact your prayers do not count the angels who gained and means a kind of anxiety that is in the heart of the angels who has lost their composure.

In the phrase:

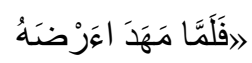

The "السماء" is part of the land but all the land is concerned that in the terms of " الأرض or " is used. 
The difference between these two words meaning is believed indicate that صدر is setting of animal soul so it is the very place where the evil influences. If the قلب of the throne and the rational soul is official therefore the evil in the قلب cannot be effective (Mulla Sadra, 1988). But some scholars believe that there are some differences in meaning between the two words, of course, both mean 'heart'.

رجاء in this phase:

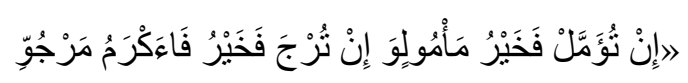

It is semantically different that is why the "أمل " means to think happening of something that its reality is unlikely it means wish, and "رجاء " means hope and expect to achieve the obtainable righteous (Mostafavi, 1981). Since you can also have demands from God that the acquisition is unlikely and expect to achieve everything that is good and is the best resource for people therefore the use of these words with the concepts is appropriate.

\subsection{Repetition and emphasize}

Imam Ali (peace upon him) whenever feels they are in a situation that might cause in problems for the reader in understanding or even denies an entry or event, he deals voluntary or involuntary reiteration and emphasis.

For example, repeating the word "كل" in the:

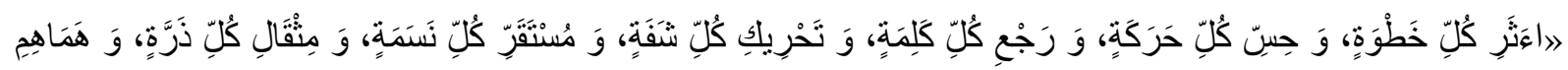
كُلِّ نَفْسِ هَامََّةِّنِ

And repeating the word "اللهم" in the clause:

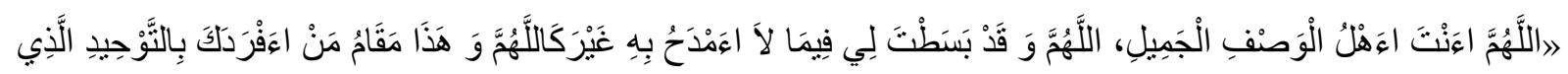
هُوَ لَكَّه؛

In addition to the emphasis on meaning it is added to literal beauty of the words.

Or in terms of emphasis:

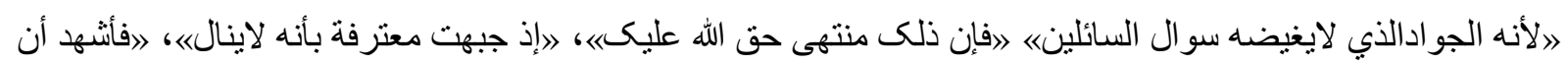

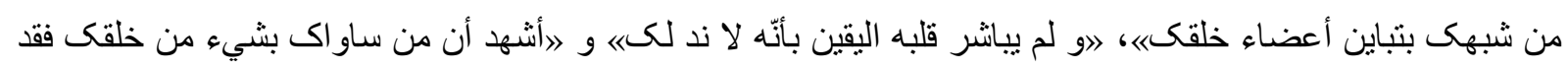

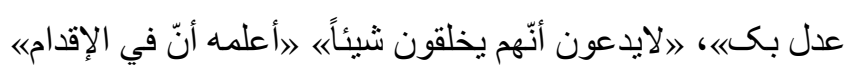

The term " أنّ and إنّ ".

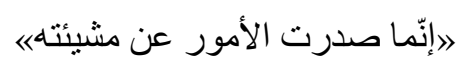


The term "إنما"

$$
\text { "إنك أنت الله الذي لم تنتاه في العقول《« }
$$

Season pronoun "أنت" and the word " إنّ" are used to add emphasis to the meaning.

\subsection{Using definiteness and indefiniteness in the words}

Using words as definiteness and indefiniteness in this sermon is not without reason. For example, in the phrase;

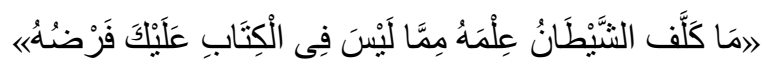

Using “"الكتاب" as definiteness; is for book of God is not any kind of book. Or in the:

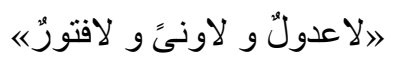

Using names as indefiniteness is for generalization of the meaning it means angels never falter and do not lose faith on the earth.

\subsection{The preposition}

The preposition "من" at statements:

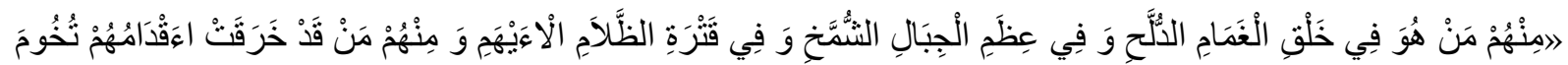

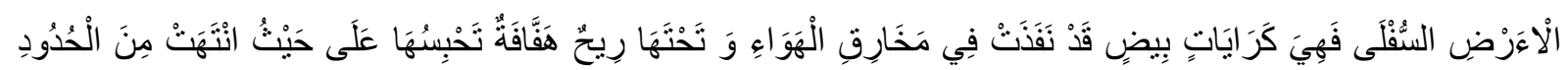
الْْنَتَاهِيَةِة

Come to convey the meaning of "some".

\subsection{Eloquence of words}

Use of words that have slight movements causes in eloquence of the words but it does not mean that the use of heavy moving of lacks the eloquence of words. In this sermon also we saw the use of eloquent words to the benefit of the words that the movements are mild and words with the heavy movement of because hasn't an unreasonable use but to comply with rhyme and rhythm and intonation were added. (Abdul Hamid Naji, 1984) Use of words such as "سُبُحات , سُتُرات and... In this sermon, despite the heavy movement of $\dot{8}$ he has used it to create a rhyme with the words next to it and to have the eloquence of words. 


\section{Level of syntax}

Any literary work consists of components that are connected to each other and the main concept of the work is relations with each component with another component, and by analyzing the relationship between these components, the implied meaning can be found that is called level of syntax.

Imam Ali (peace upon him) shows great care in choosing suitable words in terms of verbal or nominal sentences of this sermon in order to create a work that every structure is compatible with the intended meaning. The following are examples of proportion of meaning and structure:

\subsection{Sentence structure}

As this is a long sermon we suffice in mentioning a few examples of the structure of sentences.

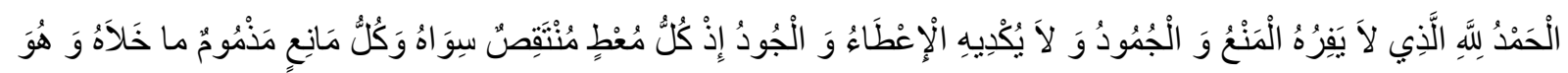

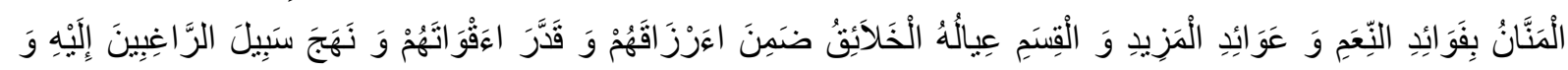

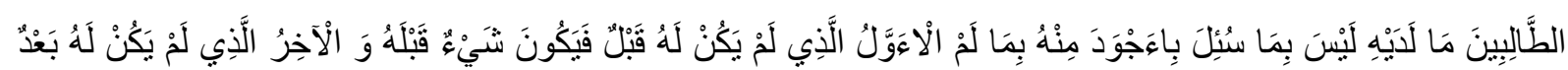

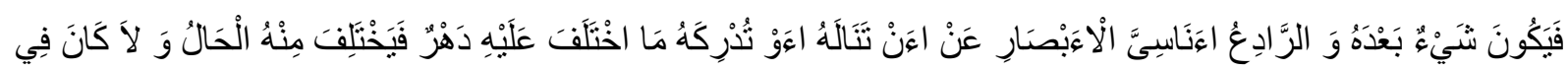

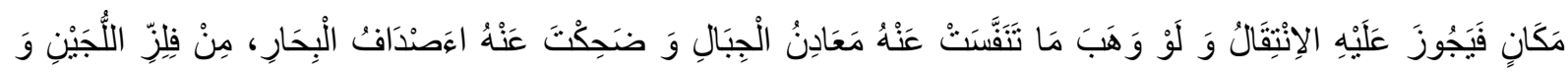

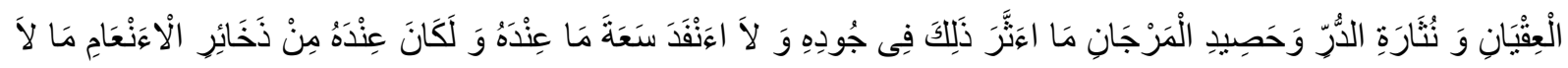

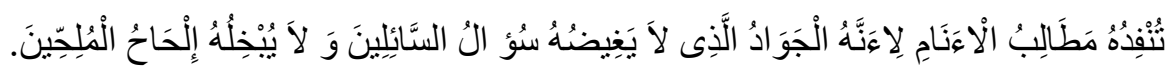

At the beginning of the sermon he has used " الحمد "as it was a more common word, and it is used nominal sentences to describe in the above statements the Divine Being for His permanent and consistent being. But for describing the gift of God's grace toward creatures he has used verbal statements because the property is a creation of God and thus ends by grace of God therefore giving verbal statement is consistent with such themes as:

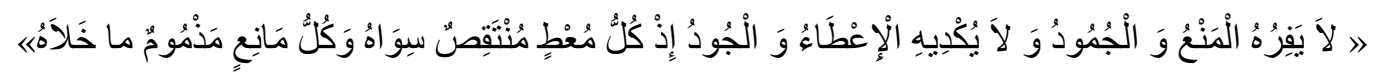

And also about the forgiveness of God in everything that it is not permanent, verbal sentences are used:

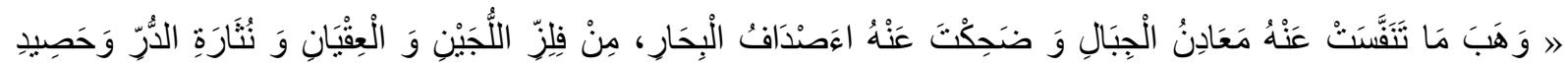

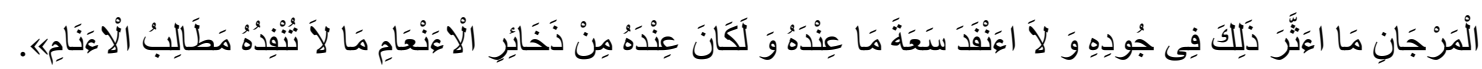


Also to embody the attributes of God in the minds of the audience present continuous verbs are used.

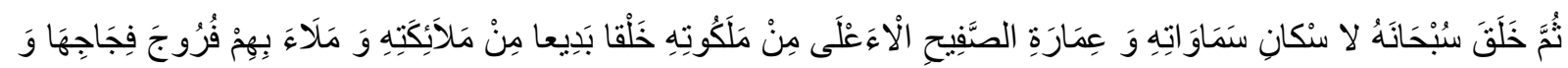

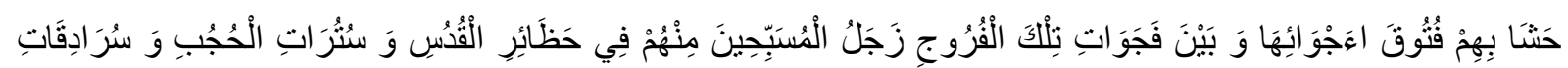

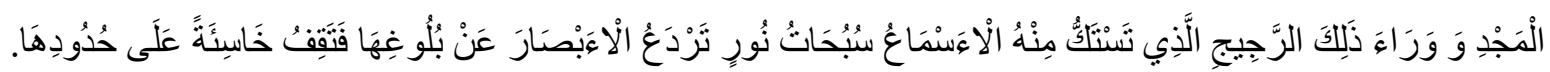

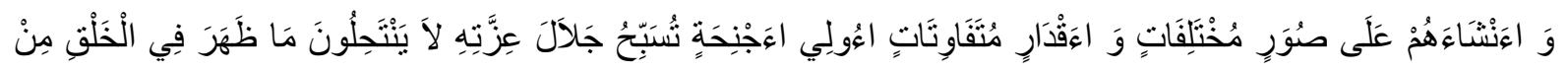

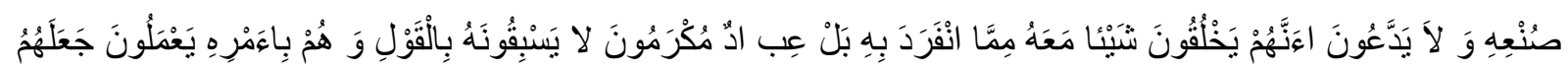

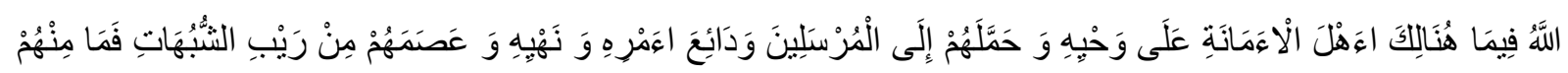

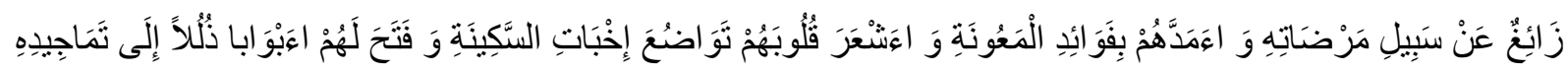

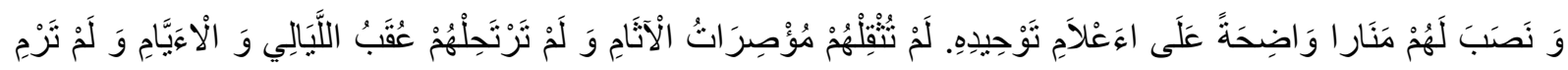

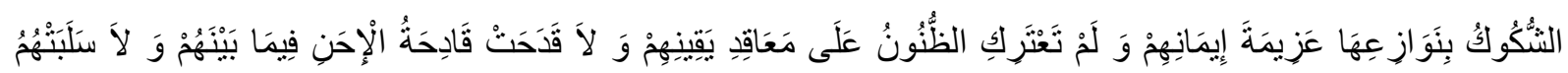

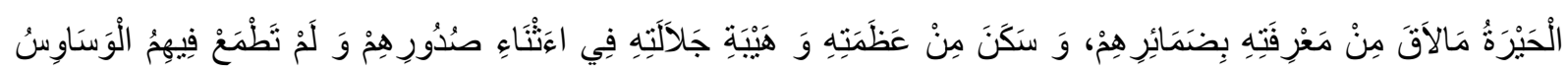

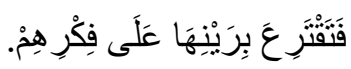

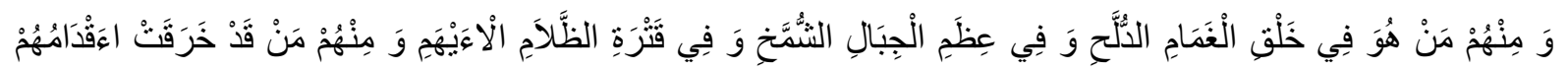

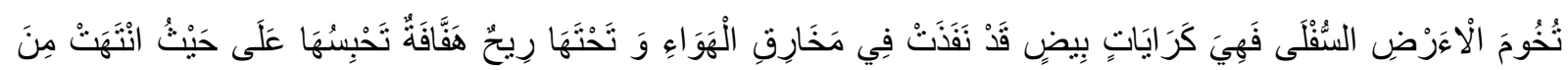

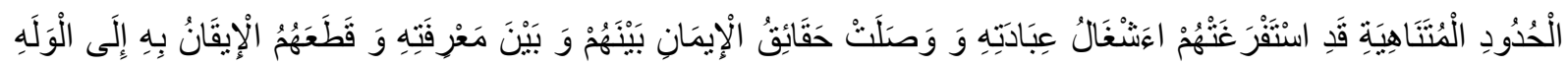

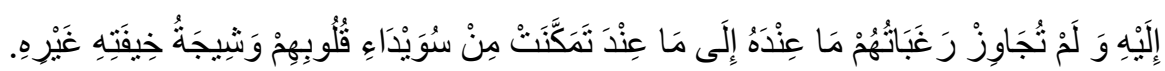

In the above phrases the proper use of verbal and nominal sentences is evident since the creation of the heavens to accommodate the angels, how angels were created and given wings and establish traits such as chastity, humility and obedience to their existence and... are as issues in cross-sectional moment, so these concepts and the creation of creatures are suitable to be stated with verbal sentences but the goal of creating the angels, the reason of this creation and the impact that the creation leave are as permanent issues, therefore in this phrase:

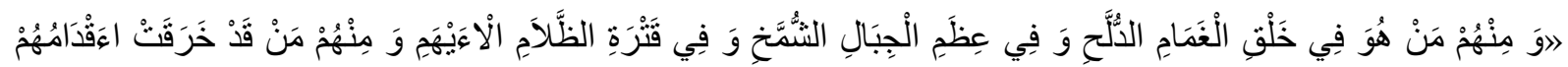

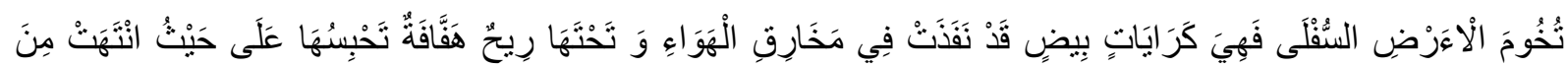

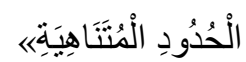

Nominal sentences was used instead because angles are in two categories and never are misled in any way and under any circumstances are believed servants, these factors are part of the fixative and permanent properties of them.

With the consideration of application of verbal and nominal sentences in this sermon it can be concluded that in the sentences that the attributes of God are only used the sentences are in 
terms of nominal sentences to prove the permanent features are only for God. As well as to determine the continuity in praise of God, the need of man to God the present continuous verbs have been used because this verb expresses the continuation.

\subsection{Interrogation}

Interrogation is demand for awareness that the answer it is not clear to the questioner and interrogation with regard to the context and the context in semantics, negation, proof, denial, and wonder ... is being used. In the below phrase it is used for denial:

$$
\text { 》فكيف و إنّما صدرت الأمور عن مشيئتهش《 }
$$

\subsection{Precession and retardation of the words}

Precession and retardation that have been presented in this sermon was not unduly for example, the term:

$$
\text { 》فهب لنا في هذا المقام رضاك« }
$$

Precession and retardation of:

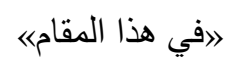

to "رضاك" is due to the more emphasis on the meaning and for creating rhyme " رضاك is with the word "سواك" in the:

$$
\text { "او أغننا عن مد الأيدي إلى سواك《، }
$$

\subsection{Imperative and prohibition verbs}

The use of the verbs in the clause is for prohibition:

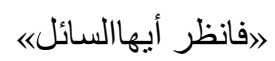

And in this phrase:

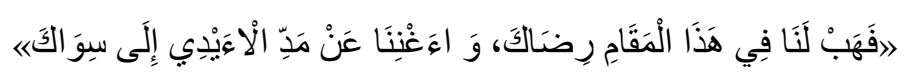

Is for command and pray, and other verbs of imperative and prohibition in this sermon have been given for guidance. 
It should be noted that all the above cases are evidences of proportion of meaning and style as well as they are appropriate in the way to use these words and phrases in place with emotional feelings of Imam Ali (PBUH).

\section{Conclusion}

In this paper some sparkles of stylistics elements in the Ashbah sermon were analyzed, the results of this study are as follows:

Living, social conditions and responsibilities of Imam Ali (PBUH) as the Imam have impelled him toward ethical, unity and religious issues.

Each of the three levels of the style has been used in proportion with meaning and concepts of sermon.

Since every literary work has its own tempo music; the result of unilateral contracts in the same sermon are due to special links between many levels including semantic, rhetorical, lexical and syntactic levels, which has established.

Considering the phonetic level demonstrate that the sermon represents the appropriate use of the Arabic language to express feelings of Imam Ali (PBUH).

Because the concepts of sermon should be worthy of public understanding therefore in this sermon, vocabulary, fluency and coherence of words has been noted.

In terms of proof vocabulary the applications of eloquent words and their compatibility with sound, sentence structure and meaning are considered.

In terms of syntax and sentence structure; Imam Ali (PBUH) has used verbal statements to address sectional issues as they arise and nominal sentences to express constancy and routine matters such as describing the attributes of God in this sermon and present continuous verbs has been used for reconstruction of events and maintenance, these points are due to congruence of words and meaning. 


\section{References}

Abbas, Hassan (1998). Arab Characteristics and Meanings of the Letters. Damascus: Union of Arab Publications Book.

Abdul Hamid, Naji, Glorious (1984). Rhetoric Psychological Foundations of the Methods Arab Emirates. Beirut: The Foundation for University Studies and Publishing.

Agilton, Terry (1995). Literary Theory. Translation by Thaer Depp. Damascus: The Ministry of Culture.

Ayyad, Mahmud (1981). Stylistic Modern - Trying to Define. Magazine Seasons, 1(2). Egyptian General Authority of the Book.

Hemase, Abdul Latif, Muhammad (1990). Arabic Syntax. Cairo: Khanji library.

Imam Ali (n.d.). Nahjol Balaqeh.

Jardaq, George (1987). Nahjol Balaqeh Wonders. Translation by Fakhr al-Din Hijazi. Tehran: Beesat Pub.

Masdi, Abdul Salam (1947). Stylistic and Style. Libya \& Tunisia: Arab House for a Book.

Mohseni, Ahmad (2004). Poetry and Music Row. Mashhad: Ferdowsi University.

Mostafavi, Hassan (1981). Inspection of Words al-Karim. Vol 4. Tehran of Translation and Publishing.

Mulla Sadra, Muhammad bin Ibrahim (1988). Tafsir al-Quran al-Karim. Research of Muhammad Khajouie. Second Edition. 1Vol. Qom: Bidar.

Perrin, Lawrence (1994). About Poetry. Translation Fatemeh, Rakei. Tehran: Information.

Qudaamah, Ben Jaafar, Abulfaraj (1963). Critique Poetry. Achieving Full Mustafa. Baghdad: Library.

Raghib Isfahani, Hussein bin Muhammad (1991). In a Strange Vocabulary of the Quran. Daudi Achieve Safwan Adnan. Beirut: Dar Mmaize.

Rajehi, Abdo (1981). Linguistics and Literary Criticism. Magazine Seasons. Magazine Seasons, 1(2). Egyptian General Authority of the Book.

Shamisa, Cyrus (2002). The Witness Game in Persian Literature. Tehran: Paradise Pub.

Wahba, Magdi (1974). Dictionary of Literary Terms. Beirut: Lebanon's Library. 